\title{
How does phytic acid decrease the absorption of elements in the digestive tract?
}

\author{
T. Szkudelski \\ Animal Physiology and Biochemistry Department, Agricultural University of Poznań \\ Wolyńska 35, 60-637 Poznań, Poland
}

(Received 23 March 1995; accepted 28 April 1995)

\begin{abstract}
Phytic acid occurs in considerable amounts in the seeds of many plants. The unique structure of this compound endows it with a high affinity for all polyvalent cations and the ability to form chelates. The solubility of these complexes is very low, especially in the presence of calcium. The interactions of phytates with proteins are an additional factor worsening the availability of the ions bound in these structures. That is why phytic acid is a factor reducing the absorption of elements from the digestive tract and its presence in food can lead to deficiencies of micro- and macroelements. This adverse effect can be limited by adding phytases to feed so as to hydrolyse phytates. If the feed contains large amounts of such endogenous enzymes, it is sufficient to soak it before feeding to animals.
\end{abstract}

KEY WORDS: phytic acid, minerals, absorption

Changes in the dietary habits of mean leading to increased consumption of food of plant origin and increasing proportions of various types of seeds, cereals and their products in the diet results in an increased intake of phytic acid. Plant components containing significant amounts of phytic acid (e.g. wheat bran) often make up also an important part of the rations fed to animals.

The considerable interest that phytic acid has raised results, among others, from the fact that its presence in feed decreases the absorption of many elements from the digestive tract, which can lead to their deficit in the body.

This review of the literature is an attempt to explain the mechanism by which phytic acid impairs the absorption of many micro- and macroelements from the digestive tract.

Phytic acid (a hexaphosphoric ester of inositol) occurs in many plant products. Cereal grain and the seeds of oil plants and legumes are particularly 
rich in this compound (Reddy, 1982). Phytic acid content in seeds varies even within the same species and may reach the level of $2 \%$ of dry matter (Reddy, 1982). Detailed information on the phytic acid contents in plant products are given in the paper by Harlad and Oberleas (1987). Phytic acid contains 60-90\% of the total phosphorus in seeds (Lolas et al., 1976) and occurs in the form of phytates, usually as mixed calcium-magnesium-potassium salts (Reddy, 1982; Lott, 1986). This makes it a storehouse of phosphorus and other elements which are released during germination through the degradation of phytates by the phytases present in seeds (Williams, 1970; Lolas and Markakis, 1977).

It was often observed that the presence of phytic acid in feed is not without effect on man or animals. The unique structure of this compound gives it very high affinity to all polyvalent cations, especially zinc (Turnland, 1984), iron (McCance et al., 1943), manganese (Davies and Nightingale, 1975), copper (Davies and Nightingale, 1975), calcium (Graf, 1983; Lonnerdal et al., 1989), magnesium (Sandberg et al., 1982) and others. Maddaiach et al. (1964) and Vohra et al. (1965) have shown, however, that the affinity of phytic acid is different to different cations and dependent on $\mathrm{pH}$.

The binding of many elements in phytates may significantly decrease their absorption and reabsorption from the digestive tract, leading to deficit of micro-and macroelements. This is the most frequently observed effect of phytic acid in feed (Davies and Nightingale, 1975; Flanagan, 1984; Lonnerdal et al., 1989; Brink et al., 1991). The manner in which phytic acid decreases the availability of elements is complex and depends on a number of factors. In a molecule of phytic acid, six phosphoric acid residues are linked by ester bonds with six carbons to which twelve hydrogens are jointed in the inositol ring. Half of these hydrogens are highly acidic $(\mathrm{pK}=1.8)$, two are weakly acidic $(\mathrm{pK}=6.3)$, and four are very weakly acidic (Bare et al., 1954). This structure determines the high binding potential of phytic acid to cations, including its ability to form chelates, and its high affinity to all positively charged molecules (Graf, 1983; Nolan et al., 1987). One molecule of phytic acid can bind up to six bivalent metal cations and the binded cation can attach the next molecule of phytic acid. As a result, structures insoluble over a wide $\mathrm{pH}$ range are formed (Graf and Eaton, 1990). An exception is the situation when there is only one cation per molecule of phytic acid. Such phytates are easily soluble and can be formed in the presence of sufficiently large amounts of phytic acid (Graf, 1983; Graf and Eaton, 1984). The solubility of phytates is, therefore, dependent to a large extent on the ratio of metal to phytic acid.

Among the many elements, calcium plays an exceptionally important role in determining the behaviour of phytates in the digestive tract (Nahapetian and Young, 1980). Kaufman and Kleiberg (1971) demonstrated that in the absence of cations and in an approximately neutral $\mathrm{pH}$, hydrogen bonding occurs between 
neighbouring phosphoric acid groups in the phytic acid molecule. These bonds are broken in the presence of calcium and very stable calcium phytates are formed. Relatively high concentrations of calcium cause the phytates to precipitate over a wide range of $\mathrm{pH}$, even at $\mathrm{pH}=2$ (Graf, 1983). It was observed, for example, that complexes of phytic acid with zinc and calcium are less soluble in the small intestine than when phytic acid is bound only to zinc (Oberleas et al., 1966). In effect, a high level of dietary calcium can significantly decrease the degree of hydrolysis of phytates in the digestive tract (Nahapetian and Young, 1980). This explains why sodium phytate can decrease the absorption of calcium in the digestive tract, leading to a deficiency of this element in the body (Reddy et al., 1982).

An additional factor that makes release of ions difficult once they have bound to phytic acid is the ability of phytates to interact with protein. In a low $\mathrm{pH}$, the negatively charged phosphate groups of phytic acid form electrostatic bonds with positively charged groups of amino acids (e.g. with the $-\mathrm{NH}_{3}{ }^{+}$group of lysine) leading to the formation of insoluble complexes (Cheryan, 1980; Scheuermann et al., 1988). In an alkaline environment, however, phytate-protein interaction occurs through polyvalent cations; this also limits the utilization of the ions that are bounds in these structures.

Hydrolysis of phytates liberates the ions chelated with phytic acids and makes them available for metabolism. Hydrolysis does not have to be complete because the less phosphorylated forms of inositol are significantly less able to bind cations and to precipitate with calcium (Thomas and Tilden, 1962; Lonnerdal et al., 1989). The degradation of phytates can occur in the digestive tract and may be catalyzed by enzymes occurring in plants, intestine or microorganisms (Sandberg and Anderson, 1988; Fredsdorff and Brummer, 1992; Pallauf et al., 1992). The role of particular enzymes in the degradation of phytates in the digestive tract is still not fully explained, although it is known that the formation of poorly soluble phytic acid salts inhibits the hydrolysis (Hallberg et al., 1991) and significantly increases the amount of phytates excreted in faeces (Nahapetian and Young, 1980).

Creating and maintaining the appropriate conditions in which the solubility of phytates in the digestive tract would increase is rather complicated. It is much easier to increase the absorption of minerals from the digestive tract if the cause of their poor absorption is binding by phytic acid. One of these ways is increasing the degradation of phytates in the digestive tract by adding bacterial phytases to feed (Pallauf et al., 1993; Mroz et al., 1994). It was found that the addition of this enzyme to the feed of young pigs increased not only the absorption of cations (mainly calcium and zinc) but also improved phosphorous and nitrogen retention (Pallauf et al., 1993; Mroz et al., 1994). This may be the result of increased digestibility of proteins after their release from phytates. 
In the case of feeds rich in phytases, a technique of decreasing the phytate content is to soak the feed for a certain period of time before feeding (Larsen, 1993). This treatment can increase the absorption of magnesium, iron, zinc, manganese and calcium in the digestive tract because of increased degradation of phytates; due to this treatment the retention of phosphorus is also increased (Larsen, 1993).

Paying more attention to phytic acid is important from the practical point of view, since this compound unpairs the absorption of many elements from the digestive tract, and can be the cause of decreased performance of farm animals. Other effects of phytic acid on the body are also known, including beneficial ones. This is, however, a topic beyond the scope of this article.

\section{REFERENCES}

Barré R., Courtois J.E., Wormser G., 1954. Étude de la structure de l'acide phytique au moyen de ses courbes de titration et de la conductivité de ses solutions. Bull. Soc. Chem. Biol. 36, 455-474

Brink E.J., Dekker P.R., Beresteijn E.C.H., Beynen A.C., 1991. Inhibitory effect of dietary soybean protein vs. casein on magnesium absorption in rats. J. Nutr. 121, 1374-1381

Cheryan M., 1980. Phytic acid interactions in food systems. CRC Crit. Rev. Food Sci. Nutr. 13, $297-335$

Davies N.T., Nightingale R., 1975. The effects of phytate on intestinal absorption and secretion of zinc, and wholebody retention of zinc, copper, iron and manganese in rats. Brit. J. Nutr. 34, $243-258$

Flanagan P.R.. 1984. A model to produce pure zinc deficiency in rats and its use to demonstrate that dictary phytate increases the excretion of endogenous zinc. J. Nutr. 114, 471-477

Fretzdorff B., Brummer J.M., 1992. Reduction of phytic acid during breadmaking of whole-meal breads. Cercal Chem. 69, 266-270

Graf E., 1983. Calcium binding to phytic acid. J. Agric. Food Chem. 31, 851-855

Graf E., Eaton J.W., 1990. Antioxidant functions of phytic acid. Free Rad. Biol. Med. 8, 61-69

Graf E., Eaton J.W., 1984. Effect of phytate on mineral bioavailability in mice. J. Nutr. 114, $1182-1198$

Hallberg L., Brune M., Erlandson M., Sandberg A.S., Rossander-Hulten L., 1991. Calcium: effect of different amounts on non-heme and heme iron absorption in humans. Amer. J. Clin. Nutr. 53, $112-119$

Harland B.F., Oberleas D., 1987. Phytate in foods. World Rev. Nutr. Diet 52. 235-259

Kaufman B., Kleiberg N., 1971. Effect of pH on calcium binding by phytic acid and its inositol phosphoric derivatives and on the solubility of their calcium salts. Arch. Oral Biol. 16, 445-460

Larsen T., 1993. Dephytinization of a rat diet. Biol. Trace Element Res. 39, 55-71

Lolas G.M., Markakis P., 1977. The phytase of navy beans (Phaseolus vulgaris). J. Food Sci. 42. 1094-1106

Lolas G.M., Palamidis N., Markakis P., 1976. The phytic acid-total phosphorus relation in barley, oats, soybean and wheat. Cereal Chem. 53, 867-871 
Lott J.N.A., Ockenden I., 1986. The fine structure of phytate-rich particles in plants. In: E. Graf. Phytic acid: chemistry and applications. Minneapolis, MN: Pilatus Press pp. 43-55

Lonnerdal B., Sandberg A.S., Sandstrom B., Kunz C., 1989. Inhibitory effects of phytic acid and other inositol phosphates on zinc and calcium absorption in suckling rats. J. Nutr. 119, 211-214

Maddaiach V.T., Kurnick A.A., Reid B.L., 1964. Phytic acid studies. Proc. Soc. Exp. Biol. Med. 15 , 391-393

McCance R.A., Edgecombe C.N., Widdowson E.M., 1943. Phytic acid and iron absorption. Lancet $2,126-128$

Mroz Z., Jongbloed A.W., Kemme P.A., 1994. Apparent digestibility and retention of nutrients bound to phytate complexes as influenced by microbial phytase and feeding regimen in pigs. $J$. Anim. Sci. 72, 126-132

Naphatelian A., Young U.R., 1980. Metabolism of ${ }^{14} \mathrm{C}$-phytate in rats: effect of low and high dietary calcium intakes. J. Nutr. 110, 1458-1472

Nolan K.B., Duffin P.A., McWenny D.J., 1987. Effects of phytate on mineral bioavailability. In vitro studies on $\mathrm{Mg}^{2+}, \mathrm{Ca}^{2+}, \mathrm{Fe}^{3+}, \mathrm{Cu}^{2+}$, and $\mathrm{Zn}^{2+}$, (also $\mathrm{Cd}^{2+}$ ) solubilities in the presence of phytate. J.Sci. Food Agric. 40, 79-85

Oberieas D., Muhrer M.E., O'Bell B.L., 1966. Dietary metal complexing agents and zinc availability in the rat. J. Nutr. $90,56-62$

Pallauf J., Rimbach G., Pippig S., Schindler B., Most E., 1993. Effect of phytase supplementation to a phytate-rich diet based on wheat, barley, and soya on bioavailability of dietary phosphorus, calcium, magnesium zinc and protein in piglets. Agrobiol. Res. 47, 39-48

Pallauf J., Hohler D., Rimbacg G., 1992. Einfluß einer Zulage on mikrobieller Phytase zu einer Mais-Soid-Diat auf die Scheinbare Absorption von Phosphor und Kalzium beim Ferkel. J. Anim. Physiol. Anim. Nutr. 67, 30-40

Reddy N.R., Sathe S.K., Salunkhe D.K., 1982. Phytates in legumes and cereals. Advan. Food Res. $28,1-92$

Sandberg A.S., Hasselblad C., Hasselblad K., Hulten L., 1982. The effect of wheat bran on the absorption of minerals in the small intestine. Brit. J. Nutr. 48, 185-191

Sandberg A.S., Andersson H., 1988. Effect of dietary phytase on the digestion of phytate in the stomach and small intestine of humans. J. Nutr. 118, 469-473

Scheuermann S.E., Lautzsch H.J., Menke K.H., 1988. In vitro und in vivo Untersuchungen zur Hydrolyse von Phytat.1. Loslichkeit von Phytat. J. Anim. Physiol. Anim. Nutr. 60, 55-63

Thomas W.C., Tilden M.T., 1972. Inhibition of mineralization by hydrolysates of phytic acid. Johns Hopkins Med. J. 131, 133-142

Turnlund J.R., King J.C., Keyes W.R., Gong B., Michel M.C., 1984. A stable isotope study of zinc absorption in young men: Effects of phytate and $x$-cellulose. Amer. J. Clin. Nutr. 40, 1071-1077

Vohra P., Gray G.A., Kratzer F.H., 1965. Phytic acid-metal complexes. Proc. Soc. Exp. Biol. Med. $120,447-449$

Williams S.G., 1970. The source of phytic acid in the wheat grain. Plant Physiol. 45, 376-381 


\section{STRESZCZENIE}

\section{W jaki sposób kwas fitynowy zmniejsza absorpcję pierwiastków z przewodu pokarmowego?}

Kwas fitynowy występuje w znacznych ilościach w nasionach wielu gatunków roślin. Unikalna struktura tego związku jest przyczyną jego wysokiego powinowactwa do wszystkich wielowartościowych kationów z możliwością tworzenia kompleksów chelatowych. Rozpuszczalność tych kompleksów w przewodzie pokarmowym jest bardzo mała, zwłaszcza w obecności wapnia. Interakcje fitynianów z białkami są dodatkowym czynnikiem pogarszającym dostępność pierwiastków włączonych w te struktury. Dlatego kwas fitynowy jest czynnikiem obniżającym absorpcję pierwiastków z przewodu pokarmowego, a jego obecność w pokarmie może prowadzić do niedoboru mikro- i makroelementów w organizmie. To niekorzystne działanie kwasu fitynowego można ograniczyć dodając do paszy fitazy w celu hydrolizy fitynianów. Jeśli pasza zawiera dużą ilość tych enzymów, wystarczającym zabiegiem jest moczenie jej przed podaniem zwierzętom. 